\title{
Cutaneous Lymphangioma Circumscriptum Occurred Seven Years after Surgery with Soft Tissue Cystic Lymphangioma
}

\author{
Min Je Jung, Yong Won Choi, Jee Hee Son, Hye One Kim, Bo Young Chung*, Chun Wook Park* \\ Department of Dermatology, Hallym University Kangnam Sacred Heart Hospital, Seoul, Korea
}

Lymphangiomas are rare benign congenital lymphatic malformations. They can be divided into three groups: cutaneous lymphangioma circumscriptum (CLC), cavernous, and cystic. CLC is the most common type, and rarely occurs with cavernous or cystic lymphangioma under the lesion. Here, we describe the case of a 9-year-old girl who presented with an asymptomatic vesicular lesion on her back. She was finally diagnosed with CLC by clinical manifestations, dermoscopic findings, and histologic findings. Seven years ago, there was a history of surgical operation in the department of general surgery, and the surgery was soft tissue cystic lymphangioma removal surgery. There was no skin lesion for seven years after surgery, but one occurred a month ago. Herein, we present a case of CLC that occurred after a long interval after surgery for soft tissue cystic lymphangioma. (Ann Dermatol 31(4) 450 453, 2019)

Received January 29, 2018, Revised July 4, 2018, Accepted for publication July 23, 2018

Corresponding author: Chun Wook Park, Department of Dermatology, Kangnam Sacred Heart Hospital, College of Medicine, Hallym University, 1 Singil-ro, Yeongdeungpo-gu, Seoul 07441, Korea. Tel: 82-2-829-5221, Fax: 82-2-832-3237, E-mail: dermap@hanmail.net ORCID: https://orcid.org/0000-0003-4512-8668

Bo Young Chung, Department of Dermatology, Kangnam Sacred Heart Hospital, College of Medicine, Hallym University, 1 Singil-ro, Yeongdeungpo-gu, Seoul 07441, Korea. Tel: 82-2-829-5221, Fax: 82-2-832-3237, E-mail: victoryby@naver.com

ORCID: https://orcid.org/0000-0002-2795-0140

*These authors contributed equally and should be considered co-correspondence authors.

This is an Open Access article distributed under the terms of the Creative Commons Attribution Non-Commercial License (http://creativecommons. org/licenses/by-nc/4.0) which permits unrestricted non-commercial use, distribution, and reproduction in any medium, provided the original work is properly cited.

Copyright $($ c The Korean Dermatological Association and The Korean Society for Investigative Dermatology

\section{-Keywords-}

Dermoscopy, Lymphangioma, Lymphangioma, cystic, Neoplasm recurrence, local

\section{INTRODUCTION}

Lymphangiomas are congenital lymphatic malformations that may involve the skin and subcutaneous tissues ${ }^{1,2}$. They are rare, accounting for $4 \%$ of all vascular tumors and about $25 \%$ of children's benign vascular tumors ${ }^{1}$. More than $90 \%$ of cases occur before two years of age ${ }^{1}$. They can be classified into three groups: cutaneous lymphangioma circumscriptum (CLC), cavernous, and cystic. $\mathrm{CLC}$ is the most common type $\mathrm{e}^{3,4}$. Herein, we report a case of CLC that occurred seven years after surgery for soft tissue cystic lymphangioma.

\section{CASE REPORT}

A 9-year-old girl presented with an asymptomatic vesicular lesion on her back, which was noticed a month ago. Physical examination showed a localized plaque composed of yellowish or red-colored vesicles and slightly warty papules (Fig. 1A, B). There was a linear surgical scar about $7 \mathrm{~cm}$ long around the lesion. She visited the department of general surgery with a palpable mass seven years ago. Chest computed tomography (CT) was taken at that time. On the chest CT, a mass of about $5.2 \times 2.7 \mathrm{~cm}$ was observed on the right posterior chest wall (Fig. 1C). A benign soft tissue tumor was suspected because the boundary was clear and there was no fat attenuation (Fig. 1D). It was finally diagnosed as a $5 \times 3 \mathrm{~cm}$ cystic lymphangioma. Seven years later, she revisited with a skin lesion 

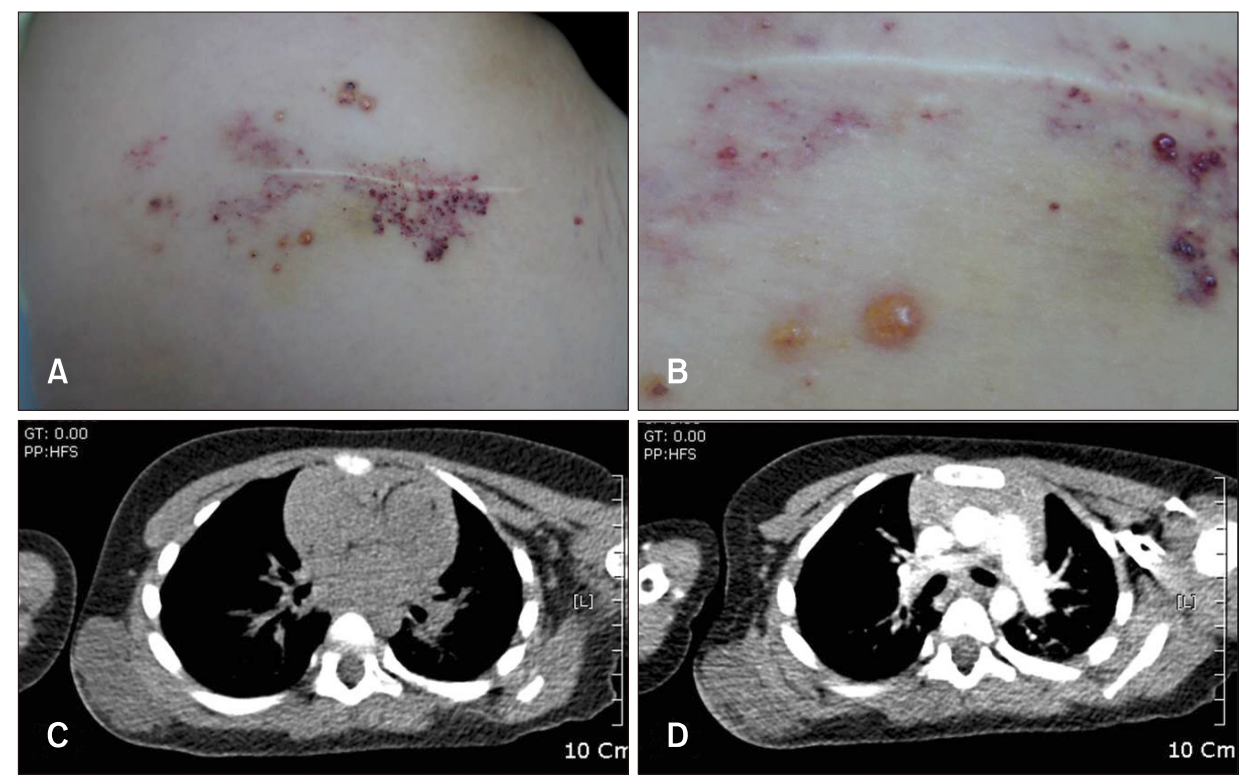

Fig. 1. (A, B) Localized plaque composed of yellowish or red-colored vesicles and slightly warty papules, is observed on the back. (C) On chest computed tomography, a mass about $5.2 \times 2.7 \mathrm{~cm}$ was observed on the right posterior chest wall seven years ago. (D) The boundary was clear and there was no fat attenuation, so a benign soft tissue tumor was suspected.
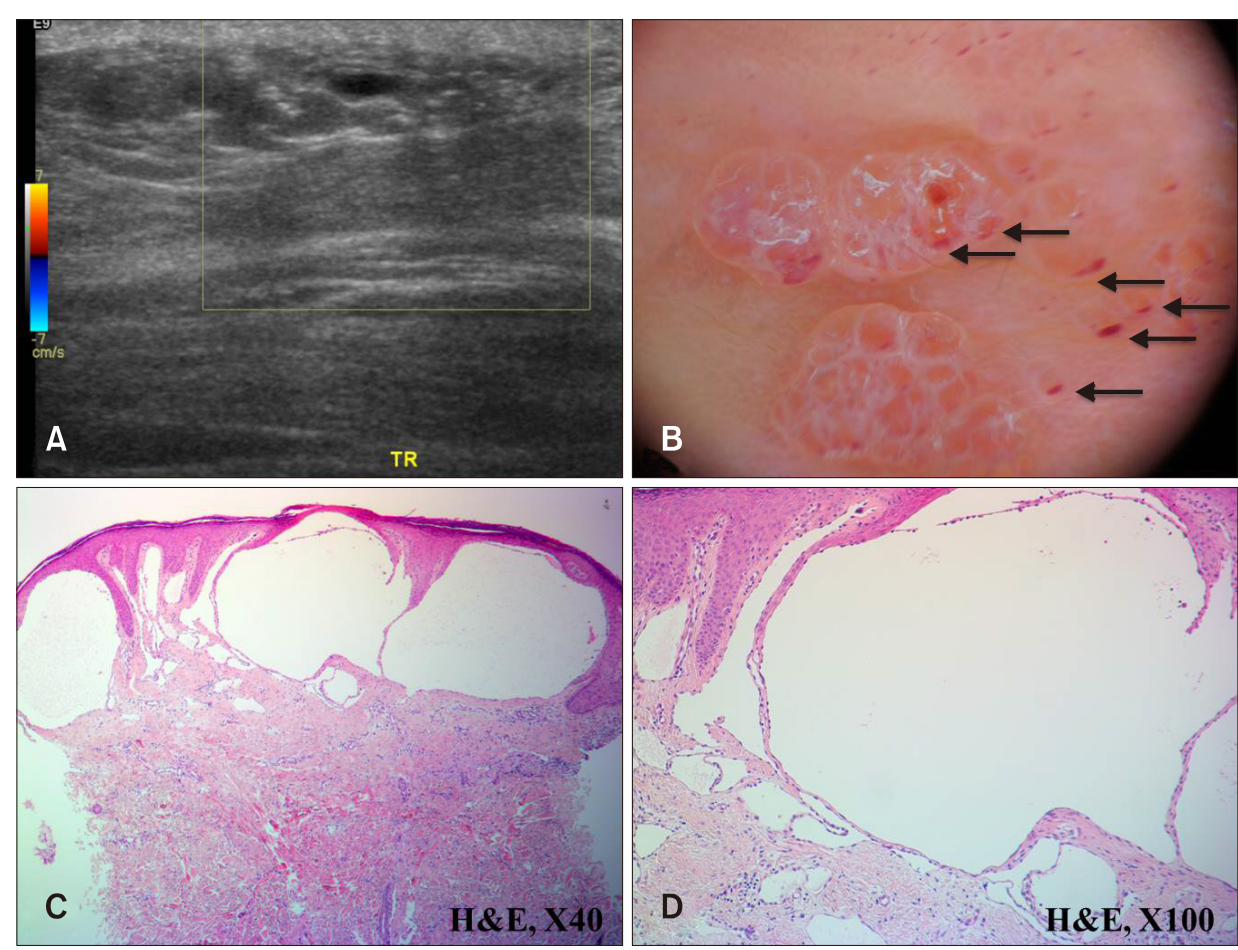

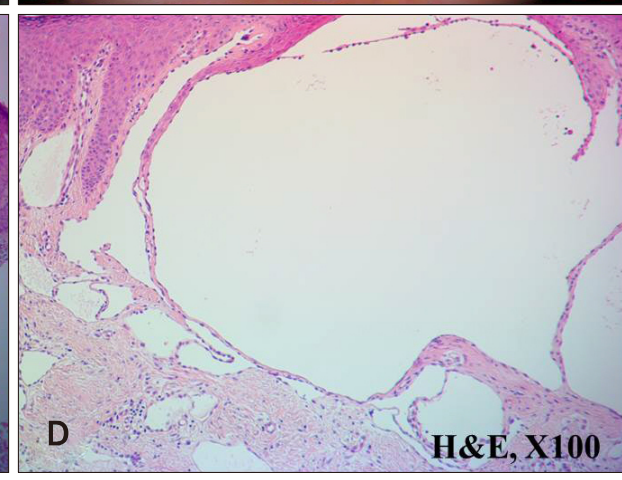

Fig. 2. (A) No soft tissue mass was observed on ultrasound. (B) By dermoscopy, light brownish lacunae with pale septa and dark-reddish areas in some lacunae were observed. Hypopyon-like features suggesting lymphangioma were observed and marked with arrows. (C, D) Histopathologic examination showed a large number of irregularly enlarged lymphatic vessels bordered by very thin lymphatic endothelial cells in the upper dermis. A pale pink lymphatic fluid was was observed (H\&E: C, $\times 40 ; \mathrm{D}, \times 100)$. and ultrasound was performed. No soft tissue mass was observed on ultrasound (Fig. 2A). Dermoscopy showed light brownish lacunae with pale septa and dark-reddish areas in some lacunae (Fig. 2B). Therefore, punch biopsy was performed under suspicious diagnosis of cutaneous lymphangioma. Histologic examination revealed a large number of irregularly enlarged lymphatic vessels bordered by very thin lymphatic endothelial cells in the upper dermis. A pale pink lymphatic fluid was observed (Fig. 2C, D).
Therefore, the final diagnosis was made of CLC. The patient is undergoing cryotherapy at three-week intervals, and carbon dioxide $\left(\mathrm{CO}_{2}\right)$ laser ablation therapy once for the remaining lesions. We received the patient's consent form about publishing all photographic materials.

\section{DISCUSSION}

CLC is characterized by a clustering of translucent vesicles 
accompanied by pink, red, or black discoloration as a byproduct of bleeding ${ }^{1}$. In dermoscopy, it is described as light brown lacunae with presence of clear fluid surrounded by pale septa. When blood infiltrates, dark-red to bluish lacunae are observed leading to hypopyon-like features due to the effect of color transition from dark to bright color $^{5-8}$. This feature is useful for differentiating from haemangioma $^{8}$. Surgical resection is the choice for primary treatment of lymphangiomas. There were reports that cryotherapy, sclerotherapy, cauterization, and carbon dioxide lasers have been used with good results ${ }^{1,9}$.

It was not difficult to diagnose our case because of typical clinical, dermoscopic, and histological findings. However, it occurred around the surgical scar site. The surgery was performed on a soft tissue mass seven years ago. It was very interesting that the mass was a soft tissue cystic lymphangioma. It is known that the recurrence rate is not high in lymphangiomas of $7 \mathrm{~cm}$ size or less, if the local excision is performed appropriately ${ }^{10}$. However, close follow-up is recommended because of the relatively high recurrence rate in children ${ }^{1}$. In the retrospective study by Alqahtani et al. ${ }^{11}$, a recurrence rate of $29 \%$ was found in 196 lesions of 186 patients during an average follow-up period of 3 years. Sixty percent of patients with relapse, recurred within one year, and eighty percent recurred within three years. It was not uncommon to have lymphangioma circumscirptum associated with cystic lymphangioma $^{12-14}$. In one series of case studies ${ }^{15}, 11$ of 61 cases of deep lymphangioma, including cavernous lymphangioma and cystic hygroma, were associated with lymphangioma circumscriptum. This probably implies a general developmental disease of the lymphatic system 1 . In the recurrent form of cystic lymphangioma, there is still no exact epidemiologic data of the ratio to CLC. However, cases were not uncommon where cystic lymphagioma and CLC were displayed together, which suggests that the two types are within the spectrum of lymphatic system malformation ${ }^{16}$. Therefore, in situations where cystic lymphangioma was incompletely resected, it seems that lymphatic malformation might appear in the superficial form, CLC.

Our patient had remained well without recurrence for seven years after surgery. Suddenly, seven years later, a CLC occurred, confined to the skin. In our case, CLC recurred from cystic lymphangioma, and there was a long interval between occurrences. Prolonged monitoring is needed in lymphangioma patients because relapse is not uncommon. Therefore, we report this case to inform the necessity of prolonged monitoring in lymphangioma patients.

\section{ACKNOWLEDGMENT}

This study was supported by grants of the National Research Foundation of Korea (NRF), funded by the Ministry of Science, ICT \& Future Planning (NRF-2017R1A2B4006252, 2018R1C1B6007998), Korea Healthcare technology R\&D project, funded by Ministry of Health \& Welfare, Republic of Korea (HI17C0597), and the Hallym University Research Fund (HURF-2017-35, HURF-2017-52, HURF-2017-83).

\section{CONFLICTS OF INTEREST}

The authors have nothing to disclose.

\section{ORCID}

Min Je Jung, https://orcid.org/0000-0002-1037-2209

Yong Won Choi, https://orcid.org/0000-0003-0607-5145

Jee Hee Son, https://orcid.org/0000-0002-7816-1942

Hye One Kim, https://orcid.org/0000-0001-5846-0008

Bo Young Chung, https://orcid.org/0000-0002-2795-0140

Chun Wook Park, https://orcid.org/0000-0003-4512-8668

\section{REFERENCES}

1. Patel GA, Schwartz RA. Cutaneous lymphangioma circumscriptum: frog spawn on the skin. Int J Dermatol 2009;48: 1290-1295.

2. Samdani AJ, Bana SH, Azam T. Lymphangioma circumscriptum: report of three cases from Saudi Arabia. Int J Dermatol 2006;45:840-842.

3. Bauer BS, Kernahan DA, Hugo NE. Lymphangioma circumscriptum-a clinicopathological review. Ann Plast Surg 1981; 7:318-326.

4. Morris M. Lymphangioma circumscriptum. In: Unna PG, Morris $M$, Duhring LA, Leloir $\mathrm{H}$, editors. International atlas of rare skin diseases. London: Lewis, 1889:1-4.

5. Massa AF, Menezes N, Baptista A, Moreira Al, Ferreira EO. Cutaneous Lymphangioma circumscriptum-dermoscopic features. An Bras Dermatol 2015;90:262-264.

6. Arpaia N, Cassano N, Vena GA. Dermoscopic features of cutaneous lymphangioma circumscriptum. Dermatol Surg 2006;32:852-854.

7. Amini S, Kim NH, Zell DS, Oliviero MC, Rabinovitz HS. Dermoscopic-histopathologic correlation of cutaneous lymphangioma circumscriptum. Arch Dermatol 2008;144:16711672.

8. Gencoglan G, Inanir I, Ermertcan AT. Hypopyon-like features: new dermoscopic criteria in the differential diagnosis of cutaneous lymphangioma circumscriptum and haemangiomas? J Eur Acad Dermatol Venereol 2012;26:1023-1025.

9. Fioramonti $P$, Maruccia M, Ruggieri M, Onesti MG. A rare case of lymphangioma in the gluteal region: surgical treatment combined with sclerotherapy and laser therapy. Aes- 
thetic Plast Surg 2013;37:960-964.

10. Browse NL, Whimster I, Stewart G, Helm CW, Wood JJ. Surgical management of 'lymphangioma circumscriptum'. Br J Surg 1986;73:585-588.

11. Alqahtani A, Nguyen LT, Flageole $H$, Shaw K, Laberge JM. 25 years' experience with lymphangiomas in children. J Pediatr Surg 1999;34:1164-1168.

12. Seber S, Köse N, Turgut A, Ozçelik A, Göktürk E. Giant cystic lymphangioma cavernousum of lower limb with overlying lymphangioma circumscriptum. J Pediatr Orthop B 2004;13:284-286.
13. Irvine AD, Sweeney L, Corbett JR. Lymphangioma circumscriptum associated with paravesical cystic retroperitoneal lymphangioma. Br J Dermatol 1996;134:1135-1137.

14. Rao MV, Thappa DM, Ratnakar C. Lymphangioma circumscriptum of the skin and tongue associated with cystic hygroma. Indian J Otolaryngol Head Neck Surg 1998;50: 266-268.

15. Flanagan BP, Helwig EB. Cutaneous lymphangioma. Arch Dermatol 1977;113:24-30.

16. Preeti A, Kumar R. Cystic hygroma: cytological and radiological co-relation. J Clin Diagn Res 2011;5:1008-1010. 